\title{
APPLICATION OF THE MODEL FOR SUPPORT DECISION IN THE CREDITING OF AGROINDUSTRY COMPLEX
}

\author{
Aleksandar Živković ${ }^{1}$, Snežana Krstić ${ }^{2}$ Nataša Simićc ${ }^{3}$ \\ *Corresponding author E-mail: profdrsnezanakrstic@gmail.com
}

\begin{abstract}
A R T I C LE I N F O
A B S T R A C T

Review Article

Received: 31 March 2019

Accepted: 15 June 2019

doi:10.5937/ekoPolj1902559Z

UDC 338.43:336.77/.78

The optimal function of the financing function is achieved through the planning process. By planning development, as one of the basic functions of management, goals, tasks and the way of their realization are determined. The realization of financing plans is realized through the function of financing with own funds, and borrowed both from the domestic and foreign markets.

Keywords:

crediting, financing, agroindustrial complex

JEL:013, Q14 The importance of financing consists in the fact that the level of reproductive capacity of the agro-industry complex depends to a considerable extent on the normative organization, organization and quality of financing. The goal of financing is precisely, timely, quality and under the most favorable conditions, the acquisition of financial resources on the market in order to meet the needs for continuous business of the subjects of the agro-industrial complex.
\end{abstract}

(C) 2019 EA. All rights reserved.

\section{Introduction}

The function of financing is realized through several subprocesses: planning; market research and price monitoring; contracting; tracking billing maturity. To this end, the application of scientific methods in the study and market research is necessary, the formation and engagement of expert teams for execution of certain financial arrangements, the implementation of complex economic analyzes, essentially looking at all relevant factors that would ensure the execution of the purchase of financial resources under the most favorable conditions.

In addition to the elements of economy, for every purchase of financial resources, justification from the point of view of real needs is important. Well elaborated financial provision plans represent a decision on what, how much and at what affordable price

1 Aleksandar Živković, Ph.D., Full Professor, Faculty of Economics, Belgrade University, Kamenička No.6, 11000 Belgrade, Serbia, Phone: +381113021047, aca@ekof.bg.ac.rs

2 Snežana Krstić, Ph.D., Full Professor, Military academy, Belgrade, Pavla Jurišića Šturma No.33,11000 Belgrade, Serbia, Phone: +381642756677, profdrsnezanakrstic@gmail.com

3 Natasa V. Simic PhD, Associate Professor, Faculty of Economics and Finance, "University Union - Nikola Tesla" Cara Dusana No. 62-64, 11000 Belgrade, Serbia; Phone: +381641678286,nsimic68@gmail.com, https://orcid.org/0000-0002-1196-891X 
they are to procure. Economic analysis in the decision-making on credit funds (Popović S, Janković I, Stojanović Ž., 2018) is an analysis of the future of events and events aimed at finding the most rational solutions based on the collected data in order to make an optimal decision. (Mihajlović et al., 2012)

The cost of financing is one of the most important elements in the process of obtaining financial resources. If the framework for the freedom to form a bidder's price is higher, that is, if the market of imperfect competition is more complex, the process of securing the financial resources being implemented. When forming the price of money on the market, it should be taken into consideration that the most common selling is done directly, which differentiates it from consumer goods. Given that loans (Marjanović, Prelić, Belokapić-Čavkunović, 2017) as a financial product are sold directly to buyers, the degree of control over the price is higher than the sales made by consumables. (Rađenović, 2015)

The agro-industrial complex significantly reflects the lending of providing capital equipment. In financing such funds, selecting the credit structure (Bai, at. All., 2019) of financial assets is dominant as a fact that determines a potential agro-producer (Mariyono, 2019), which is also the subject of research in this paper.

The idea of how people make decisions is as old as the civilization itself, and it is presented through a variety of theories. These theories are not characterized as strict scientific approaches that are encountered in literature. It is therefore not surprising that literature in decision-making is in constant progress. What is common to all decision makers is that the decision is the most important task of each manager and that the decision-making process occupies the bulk of their working time. Bearing in mind the fact that the decision implies the choice of one of the considered alternatives, they can be made immediately or after the analysis of the problem being considered. (Petrović et al., 2012)

\section{Materials and methods}

There are a number of methods and techniques that have been developed over time and used to solve decision-making problems in real-life situations, and can all be divided into two large groups: methods of single-criterion decision making and multi-criteria decision making. The first group of methods is often referred to as the methods of operational research and include: linear programming, transport methods, nonlinear, dynamic programming, network planning, game theory, (Pamucar et al., 2012)

The second large group, the methods of multi-criteria decision-making, refer to decisionmaking situations when there are a number of, most often, conflicting criteria. It is precisely this fact that represents a significant step towards the reality of the problems that can be solved by multi-criteria decision-making methods. All classic optimization methods use only one decision-making criterion, which drastically reduces the reality of problems that can be solved. Problems that are solved using the multi-criteria decisionmaking methods have the following common characteristics: (Čupić, Suknović, 
2010) a number of criteria, that is, the attributes that must be created by the decision maker; the conflict among the criteria, as the most common case for real problems; unreparable units of measure, because as a rule, each criterion, that is, the attribute has different units of measure; design or selection. Solutions to this kind of problem are either designing the best action (alternative) or selecting the best action from a set of previously defined final actions. The problem of determining the significance of the criteria in the realization of the provision of financial resources (Tadić, 2018) through loans for the agro-industrial sector (Milić, Soleša, 2017), includes several stakes.

The term criterion takes an important place in the decision-making process on the most favorable bid. According to the direction of agreement, they differ (Pavličić, 2010): income criteria; expense criteria and non-monotonic criteria. There are numerous methods for solving the multi-criteria decision-making model, which can be divided on the basis of several criteria, and as the best in today's time, they are distinguished: ELECTRE method; method PROMETHEE; AHP methods (analytical hierarchical processes); TOPSIS method; method SAW et al.

For research purposes, we will use the AHP method, which represents the method of multi-criteria decision making, designed to assist decision-makers in solving complex decision-making issues involving a larger number of decision-makers, a greater number of criteria in multiple periods (Ahmad, at. all. 2018). Methodologically, AHP is a multi-criteria technique that is based on explaining a complex problem in a hierarchy. The method of analytical-hierarchical processes holds all the parts of the hierarchy in connection, so it is easy to see how the change of one factor influences other factors

The decision-making process is often very complex because of the presence of conflicting targets among the available criteria or alternatives. The problem is to choose an alternative that will best meet the set goals (Milojević, 2018). The field of application of this method is multi-criteria decision-making where, based on a defined set of criteria and attribute values for each alternative, the choice is most acceptable. For easier application of this method, a software tool from the Expert Choice decision support system was developed.

The process of implementing the AHP method involves four basic phases: (Čupić, Suknović, 2010) Structuring a problem that consists of decomposing any complex problem of decision making in a series of hierarchies, where each level represents a smaller number of manageable attributes. They then decompose into another set of elements corresponding to the next level. This hierarchical structuring of any decision problem in this way is an effective way of dealing with the complexity of real problems and identifying significant attributes (Cvijanović, at. all., 2013) in order to achieve the overall goal of the problem. Data collection is the beginning of the second phase of the method of analytical-hierarchical processes. The decision maker assigns relative estimates in attribute pairs, one hierarchical level, for all levels of the entire hierarchy. The most familiar scale used to assign weight is Saaty's nine-point scale. 
Estimating relative weights implies that the matrix of comparison, by pairs, translates into problems of determining its own values, in order to obtain normalized and unique own vectors, with the weights for all attributes to each level of the hierarchy.

Determining the solution to the problem is the last phase which involves finding the socalled. composite normalized vector. After the vector of the order of the values of the criteria in the model is determined, in the next round it is necessary to determine within each observed criterion, the order of importance of the alternative in the model with respect to the same procedure. The mitigating circumstance when using any method of multi-criteria decision-making is the fact that all software is supported. (available at: www.odlucivanje.fon.rs)

\section{Results and Discussion}

Using the procedure of the AHP method, we analyzed the data that we came up with by researching 60 purchases of financial assets from loans (Hai, Shi, Peng, 2013) made in the entities of the agro-industrial complex in the Republic of Serbia. Procurement was related to loans, and for the needs of the research they were grouped into three categories. The first category consisted of 20 credit arrangements where the lowest loan price (interest rate) was observed as a criterion. The second category consisted of 20 credit arrangements where the criterion was observed in addition to the price-interest rate and the terms of lending. In the third category, 20 credit arrangements were placed, in which, besides the price and terms of lending, the following criteria were used: the creditors' financial rating, the administrative obligations regarding the granting of loans and the financial capacity of the lender.

Bearing in mind that there are different elements of the criteria (Xing, 2014), the model takes the ones that are most important for providing continuous financing of the entities of the agro-industrial complex, starting from the conditions of performing this economic activity. Criteria on the basis of which the alternatives are evaluated in this case are:

Table 1: Criteria for the selection of an optimal bidder (calculation of the author)

\begin{tabular}{|c|c|c|}
\hline No. & $\begin{array}{c}\text { Criteria } \\
\text { label }\end{array}$ & Description of criteria \\
\hline 1 & $\mathrm{~K}_{1}$ & The speed of securing money. \\
\hline 2 & $\mathrm{~K}_{2}$ & Quality of credit line resources. \\
\hline 3 & $\mathrm{~K}_{3}$ & $\begin{array}{c}\text { The degree of execution expressed in percentage terms and calculated after the } \\
\text { expiry of the lending period. }\end{array}$ \\
\hline 4 & $\mathrm{~K}_{4}$ & $\begin{array}{l}\begin{array}{l}\text { Security, which refers to the time of realization - compliance with the needs for } \\
\text { money. }\end{array}\end{array}$ \\
\hline
\end{tabular}

Using the Delphi method, the values of the criteria and their relative weight are estimated:

$\mathrm{K} 1$ - loan securing rate $(0.30)$,

K2 - quality of the credit line (0.20), 
K3 - the degree of execution (0.20) and

K4 - loan security (0.30).

The decision matrix in this case is shown in Table 2:

Table 2: Decision Matrix

\begin{tabular}{|c|c|c|c|c|}
\hline \multirow{2}{*}{ Alternatives } & \multicolumn{4}{|c|}{ Eligibility criteria } \\
\cline { 2 - 5 } & $\begin{array}{c}\text { Loan Security } \\
\text { Speed }\end{array}$ & Credit line quality & $\begin{array}{c}\text { Level of } \\
\text { execution }\end{array}$ & $\begin{array}{c}\text { Security of } \\
\text { credit }\end{array}$ \\
\hline Category 1 & 5 & Satisfies & 4 & 50 \\
\hline Category 2 & 4 & Satisfies & 5 & 40 \\
\hline Category 3 & 5 & Completely satisfies & 3 & 60 \\
\hline
\end{tabular}

By quantifying this matrix, using Saaty's scale (Saaty, 1980) with nine points for assigning weight, the resulting matrix is shown in Table 3:

Table 3: Quantified input data

\begin{tabular}{|c|c|c|c|c|}
\hline \multirow{2}{*}{ Alternatives } & \multicolumn{4}{|c|}{ Eligibility criteria } \\
\cline { 2 - 5 } & $\begin{array}{c}\text { Loan Security } \\
\text { Speed }\end{array}$ & Credit line quality & $\begin{array}{c}\text { Level of } \\
\text { execution }\end{array}$ & $\begin{array}{c}\text { Security of } \\
\text { credit }\end{array}$ \\
\hline Category 1 & 5 & 7 & 4 & 50 \\
\hline Category 2 & 4 & 7 & 5 & 40 \\
\hline Category 3 & 5 & 9 & 3 & 60 \\
\hline
\end{tabular}

At the beginning of the problem processing it is necessary to start from determining the relative weight of the criterion, that is, the significance of the criteria (Florindo, at. all., 2018). To assess relative weights, Saaty's scale is used:

Table 4: Saaty's Valuation Scale

\begin{tabular}{|c|c|c|}
\hline Importance & Definition & Explanation \\
\hline 1 & Same importance & Two elements are identical in meaning to the goal \\
\hline 3 & Poor dominance & $\begin{array}{l}\text { Experience or reasoning slightly favors one element in relation to } \\
\text { the other }\end{array}$ \\
\hline 5 & Strong domninance & $\begin{array}{l}\text { Experience or judgment greatly favors one element in relation to } \\
\text { the other }\end{array}$ \\
\hline 7 & $\begin{array}{c}\text { Demonstrated } \\
\text { dominance }\end{array}$ & The dominance of one element is confirmed in practice \\
\hline 9 & Absolute dominance & Dominance of the highest degree \\
\hline $2,4,6,8$ & Between values & Compromise needed or further division \\
\hline
\end{tabular}


Table 5: Estimating Relative Weights of Criteria (Author's Calculation)

\begin{tabular}{|c|c|c|c|c|}
\hline Eligibility criteria & $\begin{array}{c}\text { Loan Security } \\
\text { Speed }\end{array}$ & $\begin{array}{c}\text { Credit line } \\
\text { quality }\end{array}$ & $\begin{array}{c}\text { Level of } \\
\text { execution }\end{array}$ & Security of credit \\
\hline Loan Security Speed & 1 & 5 & 5 & 3 \\
\hline Credit line quality & $(5)$ & 1 & 3 & $(5)$ \\
\hline Level of execution & $(5)$ & $(3)$ & 1 & $(5)$ \\
\hline Security of credit & $(3)$ & 5 & 5 & 1 \\
\hline$\Sigma$ & 1,733 & 11,333 & 14 & 4,4 \\
\hline
\end{tabular}

Table 6: Calculating own vectors of the corresponding own values

\begin{tabular}{|c|c|c|c|c|}
\hline $\begin{array}{c}\text { Eligibility } \\
\text { criteria }\end{array}$ & $\begin{array}{c}\text { Loan Security } \\
\text { Speed }\end{array}$ & $\begin{array}{c}\text { Credit line } \\
\text { quality }\end{array}$ & Level of execution & Security of credit \\
\hline $\begin{array}{c}\text { Loan Security } \\
\text { Speed }\end{array}$ & 0,577 & 0,441 & 0,357 & 0,681 \\
\hline $\begin{array}{c}\text { Credit line } \\
\text { quality }\end{array}$ & 0,115 & 0,088 & 0,214 & 0,045 \\
\hline $\begin{array}{c}\text { Level of } \\
\text { execution }\end{array}$ & 0,115 & 0,029 & 0,071 & 0,045 \\
\hline Security of credit & 0,192 & 0,441 & 0,357 & 0,227 \\
\hline$\Sigma$ & 2,056 & 0,462 & 0,260 & 1,217 \\
\hline $\mathrm{W}(\Sigma / 4)$ & 0,514 & 0,115 & 0,065 & 0,304 \\
\hline
\end{tabular}

By comparing the value of the weight of the criteria obtained by using the Saaty scale and the value obtained by applying the Delphi method, it can be concluded that the criterion of the rate of rationalization in relation to its importance given to it in practice is overestimated. Unlike him, the criterion of the degree of execution should be given greater importance, which confirms the result obtained. The quality and safety criteria are well assessed by the data obtained.

Based on the data obtained by estimating the relative weight of the criteria, one should consider the same procedure of the alternatives that are available, that is, the three categories set. A comparison of the alternatives will be done by Saaty's rock.

Table 7: Calculation of own vectors of the corresponding own values (Loan Security speed)

\begin{tabular}{|c|c|c|c|c|c|}
\hline Alternatives & Category 1 & Category 2 & Category 3 & $\Sigma$ & $\mathrm{W}(\Sigma / 3)$ \\
\hline Category 1 & 1 & $(5)$ & $(3)$ & 0,358 & 0,119 \\
\hline Category 2 & 5 & 1 & $(3)$ & 0,993 & 0,331 \\
\hline Category 3 & 3 & 3 & 1 & 1,647 & 0,549 \\
\hline
\end{tabular}

Table 8: Calculation of own vectors of the corresponding own values (Credite line quality)

\begin{tabular}{|c|c|c|c|r|c|}
\hline Alternatives & Category 1 & Category 2 & Category 3 & $\Sigma$ & $\mathrm{W}(\Sigma / 3)$ \\
\hline Category 1 & 1 & 2 & $(4)$ & 0,632 & 0,210 \\
\hline Category 2 & $(2)$ & 1 & $(4)$ & 0,398 & 0,132 \\
\hline Category 3 & 4 & 4 & 1 & 1,164 & 0,654 \\
\hline
\end{tabular}


Table 9: Calculation of own vectors of the corresponding own values (Level of execution)

\begin{tabular}{|c|c|c|c|r|c|}
\hline Alternatives & Category 1 & Category 2 & Category 3 & $\Sigma$ & $\mathrm{W}(\Sigma / 3)$ \\
\hline Category 1 & 1 & $(3)$ & 3 & 0,780 & 0,260 \\
\hline Category 2 & 3 & 1 & 5 & 1,899 & 0,633 \\
\hline Category 3 & $(3)$ & $(5)$ & 1 & 0,317 & 0,654 \\
\hline
\end{tabular}

Table 10: Calculation of own vectors of the corresponding own values (Security of credit)

\begin{tabular}{|c|c|c|c|r|c|}
\hline Alternatives & Category 1 & Category 2 & Category 3 & $\Sigma$ & $\mathrm{W}(\Sigma / 3)$ \\
\hline Category 1 & 1 & $(5)$ & $(3)$ & 0,317 & 0,105 \\
\hline Category 2 & 5 & 1 & 3 & 1,899 & 0,633 \\
\hline Category 3 & 3 & $(3)$ & 1 & 0,780 & 0,260 \\
\hline
\end{tabular}

After the formation of the comparison table, the weights in pairs for each alternative were separately calculated by the own vector. In this way, we have gained the weight of any alternatives essential for determining the solution to the problem.

After assessing the relative weight of alternatives in relation to each criterion, it is approaching determining the category of securing credit funds, which has the highest value in relation to the criteria observed. The choice of a category is based on the obtained own vector alternatives and previously obtained own vectors of the criteria. The overall priorities of the alternatives are obtained by multiplying each weight for each alternative within the observed criterion, and in the end, the results obtained are summed up.

Table 11: Selection of the most favorable creditor

\begin{tabular}{|c|c|c|c|c|}
\hline \multirow{2}{*}{ Alternative } & \multicolumn{4}{|c|}{ Eligibility criteria } \\
\cline { 2 - 5 } & $\begin{array}{c}\text { Loan Security } \\
\text { Speed }\end{array}$ & Credit line quality & $\begin{array}{c}\text { Level of } \\
\text { execution }\end{array}$ & Security of credit \\
\hline Category 1 & 0,119 & 0,210 & 0,260 & 0,105 \\
\hline Category 2 & 0,331 & 0,132 & 0,633 & 0,633 \\
\hline Category 3 & 0,549 & 0,654 & 0,105 & 0,260 \\
\hline
\end{tabular}

From Table 11 it can be concluded that after the implementation of the AHP method, in the research, the order of alternatives would be the following: "Category 1" (14\%), "Category 2" (42\%), "Category 3" (44\%), which shows that in relation to the given criteria "Category 3", ie credit arrangements where the criterion, besides the price and terms of lending, were used: the financial rating of the lender, the administrative obligations regarding the granting of loans and the financial capacities of the lenders have the greatest value.

\section{Conclusions}

The agroindustrial complex is characterized by the integrity of the production process, which also depends on the integrity of financing. The use of quantitative models can provide a good basis for the decision-maker, although in these models the decision maker's subjectivity is present, when evaluating the relative weight of criteria and 
alternatives, it can be diminished by combining several different methods of multicriteria optimization and comparison of the solution.

The application of this model in the survey found that creditors with the highest credit rating, administrative obligations in terms of granting loans and the financial capacity of lenders for institutions that implemented the operation to provide assistance to civilian authorities after floods. These credit arrangements also had the highest value in terms of the speed of implementation, which affected the adequate provision of financial resources from the producers of the agro-industrial complex. The survey found that credit arrangements where multiple criteria were used to evaluate bids were implemented more quickly.

This research has proven that creditors who have respected the deadline for securing financial resources and who had better financial capacities in line with the required level were reliable and safe, which also affected the integrity of the financing of the producers of the previous industrial complex. Also, in the research, the decision support system showed that the reliability of the lenders is correlated with its indicators of financial capacity.

\section{Ackonowledgements}

The paper is a result of the researching project VA-DH17/19

\section{Conflict of interests}

The authors declare no conflict of interest.

\section{References}

1. Mihajlović. M., Dašić, M., \& Pamučar, D. (2012), Primena AHP metode prilikom nabavke opreme za objekte ishrane u sistemu odbrane, 34. Simpozijum o operacionim istraživanjima, SYM-OP-IS 2012,. 409-412 [in English: Mihajlović. M., Dašić, M., \& Pamučar, D. (2012), Application of the AHP method for procurement of equipment for food facilities in the defense system, 34th Symposium on Operational Research, SYM-OP-IS 2012, 409-412.

2. Rađenović, Ž. (2015). The influence of the competition policy on state aid and public sector within the European union single market. FACTA UNIVERSITATISEconomics and Organization, 12(1), 83-95.

3. Petrović, D., i dr.: Menadžment i organizacija, Fakultet organizacionih nauka, Beograd, 2012. [in English: Petrović, D., et al . (2012), Management and Organization, Faculty of Organizational Sciences, Belgrade]

4. Pamučar, D., Đorović, B., Božanić, D., \& Ćirović, G.: Modification of the Dynamic Scale of Marks in Analytic Hierarchy Process (AHP) and Analytic Network Approach (ANP) through Application of Fuzzy Approach, Scientific Research and Essays, Vol. 7(1), 2012, pp. 24-37. 
5. Čupić, M., \& Suknović, M. (2010), Odlučivanje, Fakultet organizacionih nauka, Beograd, 2010. [ in English: Decision making, Faculty of Organizational Sciences, Belgrade]

6. Pavličić, D. (2010), Teorija odlučivanja, Ekonomski fakultet Beograd, Beograd, 2010. [ in English: Decision making theory, Faculty of Economics, Belgrade.]

7. Faculty of Organizational Sciences: www.odlucivanje.fon.rs

8. Saaty, T.: The Analytic Hierarchy Process", McGraw-Hill, New York. 1980.

9. Marjanović, N., Prelić, J., \& Belokapić-Čavkunović, J. (2017). The role of the National Bank of Serbia in regulation of monetary policy. Oditor-časopis za Menadžment, finansije i pravo, 3(3), 73-88.

10. Tadić, A. (2018). Liquidity risk. Oditor-časopis za Menadžment, finansije i pravo, 4(1), 139-152.

11. Popović S, Janković I, \& Stojanović Ž., (2018) The importance of bank credits for agricultural financing in Serbia, Ekonomika poljoprivrede, vol. 65, br. 1, str. 65-80

12. Milić, D., \& Soleša, D. (2017). The analysis of macroeconomic determinants of the banking sector liquidity with role in financing agricultural sector. Economics of Agriculture, 64(2), 533-550.

13. Mariyono, J., (2019) Micro-credit as catalyst for improving rural livelihoods through agribusiness sector in Indonesia, Journal of Enterepreneurship in Emerging Econoies, 11(1), pp. 98-121

14. Cvijanović, D., Trandafilović, S., \& Imamović, N. (2013) Marketing concept in terms of agricultural enterprises development in transitional countries. Economics of Agriculture, 60(1), 113-122.

15. Bai, C., at. all., (2019) Banking credit worthness: Evaluating the complex relationship, Omega, United Kingdom, 83, pp. 26-38

16. Florindo. T. J., at. all., (2018) Application of the multiple criteria decision-making (MCDM) approach in the identification of Carbon Footprint reduction actions in the Brazilian beef production chain, Journal of Cleaner Production, 196, pp. 1379-1389

17. Milojević, I. (2018) The application of Boolean algebra in solving the legal status of retired university teachers. Oditor - časopis za Menadžment, finansije i pravo, 4(3), 62-70.

18. Ahmad, D., Chani, M. I., \& Afazl, M., (2018) Impact of formal credit on agricultural output: Empirical evidence from Pakistan, Sarhad Journal of Agriculture, 34(3), pp. 640-648

19. Xing, S., (2014) Agricultural credit institution efficiency evaluation research based on data envelopment analysis, Open Cybernetics and Systemic Journal, 8, pp. 535-539

20. Hai, L., Shi, B., \& Peng, G., (2013) A credit risk evaluation index system establishment of petty loans for farmers based on correlation analysis and significant discriminant, Journal of Software, Vol. 8, No. 9, pp. 2344-2351. 